\title{
Non-Hepatitis C Virus Crioglobulinemic Vasculitis: a Case Series of Nine Patients
}

\section{Vasculite Crioglobulinêmica Não Associada ao Vírus da Hepatite C: um Relato com Nove Pacientes}

\author{
Boris A. Cruz ${ }^{(1)}$, Ana Lúcia V. de Melo(1), Achiles de Almeida Cruz Filho(1), \\ Patrícia Salomé Gouvea ${ }^{(2)}$, César José G. Soares ${ }^{(3)}$, Viviane S. Batlle ${ }^{(4)}$, \\ Maria Luiza T. Hybner ${ }^{(4)}$, Fabiana B.Goulart ${ }^{(4)}$, Paulo M. de Pádua ${ }^{(4)}$
}

\begin{abstract}
Introduction: cryoglobulinemia vasculitis $(\mathrm{CV})$ is a systemic vasculitis secondary to circulating immune complex deposition in small blood vessels. In the overwhelming majority of patients, it is associated to hepatitis $C$ virus ( $H C V$ ) infection, nevertheless it has been observed in a wide variety of diseases and in patients with no underling conditions - "essential cryoglobulinemia". Objective: to report a series of patients with non-HCV CV. Patients and Methods: a retrospective chart review of non-HCV CV patients was carried out by members of the Minas Gerais Vasculitis Study Group. Demographics, clinical, laboratory data, treatments and follow-up are reported. Results: nine patients, two men and seven women, aged a $55.3 \pm 17$ years were studied. In three patients, $C V$ was attributed to connective tissue disease and in one to a monoclonal gammopathy of undetermined significance (MGUS). Five patients presented essential cryoglobulinemia. Four patients presented bone marrow lymphoid infiltrates, but none developed overt lymphoma. All patients complained of myalgia/arthralgia. Eight patients (89\%) presented cutaneous vasculitis; four patients (44\%) had glomerulonephritis (GN) and six patients (67\%) had neuropathy. Regarding treatment, six patients responded to steroids and immunosuppressive agents. Three patients were refractory to conventional therapy and therefore were treated with rituximab. After a follow-up of $19.3 \pm 14$ months, five patients (56\%) were in partial remission and four patients (44\%) were in complete remission. Conclusion: non-HCV cryoglobulinemia may present itself as a systemic vasculitis. It should not be understood as a simple inflammatory disease, since most patients present evidence of a lymphoproliferative disorders. Treatment should include steroids and immunosuppressive agents. Refractory patients may benefit themselves from rituximab.
\end{abstract}

Keywords: systemic vasculitis, cryoglobulinemia, cryoglobulinemic vasculitis.

\section{RESUMO}

Introdução: vasculite crioglobulinêmica $(\mathrm{Vc})$ é uma vasculite sistêmica secundária à deposição de imunocomplexos circulantes em vasos saguíneos de pequeno calibre. Na maior parte dos pacientes está associada à infecção pelo vírus da hepatite C (VHC), entretanto pode ser observada em outras doenças e em pacientes sem outras condições clínicas - "crioglobulinemia essencial". Objetivo: relatar uma série de pacientes com Vc sem infecção pelo HCV. Pacientes e Métodos: foi realizada uma revisão retrospectiva dos prontuários de pacientes com Vc sem infecção pelo HCV em acompanhamento por membros do Grupo Mineiro de Estudo das Vasculites (MGVSG). Dados epidemiológicos, clínicos, laboratoriais, tratamento e seguimento são relatados. Resultados: nove pacientes, dois homens e sete mulheres, com idade de 55,3 \pm 17 anos foram incluídos no estudo. Em três pacientes, $\mathrm{Vc}$ foi atribuída a doenças difusas do tecido conjuntivo e em um paciente à gamopatia monoclonal de significado inespecífico (MGUS). Cinco pacientes apresentaram crioglobulinemia essencial. Quatro pacientes apresentaram infiltração linfóide em biópsia de medula óssea, mas nenhum desenvolveu linfoma propriamente dito. Oito pacientes (89\%) apresentaram vasculite cutânea; quatro $(44 \%)$ apresentaram glomerulonefrite $(\mathrm{GN})$ e seis $(67 \%)$ apresentaram neuropatia. Quanto ao tratamento, seis pacientes responderam à combinação de corticóide e imunossupressores. Três pacientes mostraram-se refratários a esta abordagem e receberam rituximabe. Após seguimento de 19,3 \pm 14 meses, cinco pacientes $(56 \%)$ estão em remissão parcial e quatro $(44 \%)$ em remissão completa. Conclusão: crioglobulinemia não-associada ao VHC pode se apresentar como uma vasculite sistêmica. Vc não deve ser entendida como uma doença inflamatória simples, já que a maior parte dos pacientes apresenta evidência de uma doença linfoproliferativa. $\mathrm{O}$ tratamento usual inclui corticóide e imunossupressores. Pacientes refratários podem se beneficiar com rituximabe.

Palavras-chave: vasculite sistêmica, crioglobulinemia, vasculite crioglobulinêmica. 


\section{INTRODUCTION}

Cryoglobulins are immunoglobulins that precipitate at temperatures below $37^{\circ} \mathrm{C}(98.6 \mathrm{~F})^{(1,2)}$. Although the cryoprecipitation is described as a physical "in vitro" phenomenon, that reflects a secondary immunological disturbance. In the overwhelming majority of patients, they're associated to hepatitis $C$ virus ( $H C V$ ) infection, nevertheless cryoglobulins have been observed in a wide variety of diseases including hematological disorders and systemic autoimmune diseases. Sometimes, there are no demonstrable underlying conditions and they are referred as "essential cryoglobulinemia"(1-5). In about half of the patients, the presence of cryoglobulinemia is related to specific symptomatology, usually as an immune complex-mediated small vessel vasculitis characterized by multiple organs involvement, mainly skin, renal and peripheral nerves ${ }^{(5,6)}$. Less frequently, widespread vasculitis and cancer may complicate the clinical course of the disease

Regarding treatment, eradication of $\mathrm{HCV}$ should be attempted in all cases of HCV associated cryoglobulinemia. Immunosuppressive agents are still the first line intervention in cases of non-HCV cryoglobulinemia, but current therapies eventually prove ineffective and $C V$ may present itself as clinical challenge ${ }^{(5,6)}$. We report a series of patients with non-HCV CV were followed by Minas Gerais Vasculitis Study Group's members (MGVSG).

\section{PATIENTS AND METHODS}

The MGVSG's members were invited to report patients with non-HCV CV. The MGVSG is a multi-disciplinary and multi-institutional project developed in Minas Gerais to study clinical, epidemiologic and therapeutic aspects of vasculitis and to promote diffusion of knowledge in our medical community. Nowadays the MGVSG has more than a hundred surgeons and clinicians from different institutions and the most medical specialties.

All patients should fulfill some criteria to "define" cryoglobulinemia syndrome, as proposed by Ferri et al ${ }^{(5)}$ (Table 1) presenting negative HCV, HIV and HBV (hepatitis $B$ virus) negative serological tests. Cryoglobulinemia was assessed as follows: venous blood was collected in a warm syringe and stored at $37^{\circ} \mathrm{C}$ until it was clotted. After centrifugation at $37^{\circ} \mathrm{C}$, the serum was collected and stored at $4^{\circ} \mathrm{C}$ for one week. After isolation, the cryoprecipitate was quantified. Serum and/or redissolved cryoprecipitate was analyzed by immune electrophoresis and cryoglobulinemia types were classified according to Brouet et al ${ }^{(1)}$.
TABLE 1

CRITERIA FOR CLASSIFICATION OF MIXED CRYOGLOBULINEMIA SYNDROME PATIENTS PROPOSED BY FERRI ET AL $L^{(5)}$

\begin{tabular}{clll}
\hline Criteria & \multicolumn{1}{c}{ Serologic } & \multicolumn{1}{c}{ Pathologic } & \multicolumn{1}{c}{ Clinical } \\
\hline Major & $\begin{array}{l}\text { Serum } \\
\text { cryoglobulins, } \\
\text { low C4 }\end{array}$ & $\begin{array}{l}\text { Leukocytoclastic } \\
\text { vasculitis }\end{array}$ & Purpura \\
Minor & $\begin{array}{l}\text { Positive } \\
\text { Rheumatoid } \\
\text { Factor, HCV or HBV }\end{array}$ & $\begin{array}{l}\text { Clonal B cell } \\
\text { infiltrates (liver and } \\
\text { or bone marrow) }\end{array}$ & $\begin{array}{l}\text { Chronic hepatitis, } \\
\text { MPGN,peripheral } \\
\text { neuropathy, } \\
\text { skin ulcers }\end{array}$ \\
\hline
\end{tabular}

"Definitive" mixed cryoglobulinemia syndrome

1) serum cryoglobulins ( \pm low (4) + purpura + leukocytoclastic vasculitis

2) serum cryoglobulins ( \pm low (4) +2 minor clinical symptons +2 minor serological/ pathologic findings

"Essential" or "secondary" mixed cryoglobulinemia syndrome: absence or presence of well-known disorders (infectious, immunologic, or neoplastic).

Abbreviations: $\mathrm{HCV}, \mathrm{HBV}$, markers of HCV or HBV infection (anti-HCV_ HCV RNA; HBV DNA or HBsAg); MPGN, membranoproliferative glomerulonephritis.

Patients' charts were submitted to a retrospective standardized review. Demographics, clinical, laboratory data, treatment and follow-up were studied. Partial clinical remission was defined by the presence of mild symptoms such as fatigue, arthralgia/mialgia and purpura without skin necrosis responsive to steroids and requiring no additive immunosuppressive therapy. Complete clinical remission was defined by no clinical symptoms under low steroids dose (prednisone dose $\leq 10 \mathrm{mg} /$ day or equivalent) and/or stable immunosuppressive therapy (eg. azathioprine or methotrexate).

\section{RESULTS}

Nine patients, two men and seven women, aged of $55.3 \pm 17$ years were studied. Clinically, all patients complained of myalgia/arthralgia. Eight patients (89\%) presented purpura, in four was associated to necrotic skin ulcers. Four patients (44\%) had glomerulonephritis (GN). Two patients presented nephrotic range proteinuria and one of them presented a rapidly progressive GN (RPGN) and renal insufficiency. Six patients (67\%) presented axonal neuropathy. The first clinical manifestation was cutaneous vasculitis in six patients, neuropathic complains in two and edema and hypertension in one. Symptoms were presented for $15.7 \pm 12$ months before diagnosis (Table 2).

In five patients, no underlying condition was evident and they were classified as "essential" CV. In one female patient $C V$ was secondary to monoclonal gammopathy of undetermined significance (MGUS) and in three patients, $C V$ was attributed to connective tissue disease. Two of them had longstanding Sjögren's syndrome manifested by sicca 
symptoms and mild musculoskeletal complains and abruptly developed cutaneous vasculitis and peripheral neuropathy. In the third patient, cryoglobulinemia was associated to mixed connective tissue disease (MCTD). She had been treated for arthritis, Raynaud's phenomenon and interstitial lung disease associated to positive antinuclear and anti-RNP antibodies. She was in clinical remission under low dose prednisone, non-steroidal anti-inflammatory drugs and methotrexate when fever, myalgia, purpura and proteinuria developed.

Four patients had type II cryoglobulinemia, all of them had polyclonal IgG, IgM Kappa, low complement levels and rheumatoid factor activity. Four patients presented type III cryoglobulinemia (polyclonal $\operatorname{Ig} G$ ) and one of the patients with MGUS presented type I cryoglobulinemia (IgG Lambda). The patients with $C V$ secondary to connective tissue disease and one patient with essential $C V$ presented positive antinuclear antibodies. No patient had antineutrophil cytoplasmic antibody (ANCA). Seven patients were submitted to bone marrow biopsies and four of them presented lymphoid infiltrates and reticulinic fibrosis (Figure 1) but none developed overt lymphoma.



Figure 1 - Bone marrow biopsy of a patient with crioglobulinemic vasculitis secondary to mixed connective tissue disease (Patient-3). There are lymphoid infiltrates and reticulinic fibrosis.

Regarding therapy, five patients (56\%) responded to steroids and azathioprine. One patient with necrotic skin ulcers (Patient 4) was treated with steroids and cyclophosphamide. Three patients (33\%) were refractory to conventional immunosuppressive therapy that included at least a six-month course of steroids and cyclophosphamide. They were successfully treated with rituximab, administered with 1000-mg intravenous infusion on days, 1 and 15 in an outpatient clinic.
After a follow-up period of $19.3 \pm 14$ months, five patients $(56 \%)$ were in partial remission and four patients (44\%) were in complete remission of CV symptoms. The patients who received rituximab entered into complete remission and were followed for $23.0 \pm 4.6$ months after the first cycle of rituximab. Patients 1 and 2 relapsed at 18 and 10 months, respectively. They received a second dose of rituximab and achieved again clinical remission. After the second treatment with rituximab, patient 2 presented a third relapse, 18 months later and he was successfully submitted to a third rituximab cycle of treatment. Patient 3 was remained out of symptoms attributed to the $C V$ after the first treatment of rituximab, but he developed a progressive pulmonary hypertension several months later. So far, it was attributed to the underlying MCDT and he was treated with bosentan.

\section{DISCUSSION}

The term cryoglobulinemia refers to the presence of one or more immunoglobulins in serum, which precipitate at temperatures below $37^{\circ} \mathrm{C}$ and redissolve on rewarming. This is an "in vitro" phenomenon and the real mechanism(s) involved in cryoprecipitation is still obscure $^{(1,7)}$. Nevertheless, it is important to understand that is a physical epiphenomenon of an immunological disturbance that generates aberrant immunoglobulins which can be involved in pathogenic immune-complex formation and may lead to systemic small-vessel vasculitis ${ }^{2}$, 3, 5,6). In most cases, this immunological disturbance is a consequence of HCV infection ${ }^{(5-6)}$. This virus is not only hepatotropic but also lymphotropic and the pathogenic role of $\mathrm{HCV}$ in inducing and maintaining auto-immunity, systemic inflammation, clonal cell expansion and eventually malignancy is well accepted ${ }^{(7)}$. In the small percentage of non-HCV cryoglobulinemic patients, the mechanisms that trigger this immune disorder are to be determined.

This study reports a series of non-HCV CV patients. Although the number of studied subjects is small, it is representative, including patients with hematological disorders, connective tissue diseases and "essential" cryoglobulinemia. The frequency of cutaneous manifestations, peripheral neuropathy and renal disease in this series is comparable to those described in the medical literature. None of our patients developed central nervous system, gastrointestinal or major cardio-vascular events, which are rarely reported in $C V^{4-6)}$. The frequency of the different types of cryoglobulinemia is, in acordance with other series 
TABLE 2

DEMOGRAPHICS, CLINICAL FEATURES, TREATMENT AND FOLLOW-UP OF NON-CRYOGLOBULINEMIC VASCULITIS PATIENTS

\begin{tabular}{|c|c|c|c|c|c|}
\hline Patient & $\begin{array}{l}\text { Sex/ } \\
\text { Age }\end{array}$ & $\begin{array}{l}\text { Classification of } \\
\text { cryoglobulinemia }\end{array}$ & $\begin{array}{c}\text { Clinical manifestations } \\
\text { attributed to } \mathrm{CV}\end{array}$ & Treatment & Follow-up \\
\hline 1 & $M / 68$ & $\begin{array}{c}\text { Essential mixed } \\
\text { cryoglobulinemia (Polyclonal } \\
\operatorname{IgG} ; \operatorname{Ig} M \mathrm{\kappa})\end{array}$ & $\begin{array}{l}\text { Arthralgia, myalgia, purpura and } \\
\text { neuropathy }\end{array}$ & $\begin{array}{l}\text { PDN, CYC, } \\
\text { apheresis, } \\
\text { rituximab }\end{array}$ & $\begin{array}{l}\text { Resolution of all symptoms and relapse } 18 \text { months after } \\
\text { the first infusion of rituximab. Amelioration of clinical } \\
\text { and laboratory parameter after the second infusion but } \\
\text { persistent neuropathic complaints attributed to definitive } \\
\text { nerve damage. }\end{array}$ \\
\hline 2 & $F / 54$ & $\begin{array}{l}\text { Essential mixed } \\
\text { cryoglobulinemia } \\
\text { (Polyclonal IgG; IgM } \mathrm{\kappa} \text { ) }\end{array}$ & $\begin{array}{c}\text { Arthralgia, myalgia, purpura / leg } \\
\text { ulcer, neuropathy, nephrotic range } \\
\text { proteinuria and RPGN }\end{array}$ & $\begin{array}{l}P D N, C Y C, \\
\text { rituximab. }\end{array}$ & $\begin{array}{l}\text { Resolution of all symptoms and relapse } 10 \text { months after } \\
\text { the first infusion of rituximab. Amelioration of clinical } \\
\text { and laboratory parameter after the second infusion, } \\
\text { but difficult-to-treat leg ulcer. She relapsed again } 18 \\
\text { months after the second course of rituximab and received } \\
\text { successfully a third course. }\end{array}$ \\
\hline 3 & $F / 31$ & $\begin{array}{l}\text { Mixed cryoglobulinemia } \\
\text { (Polyclonal IgG; IgM } \mathrm{\kappa}) 2^{\text {any }} \text { to } \\
\text { MCTD }\end{array}$ & $\begin{array}{l}\text { Arthralgia, myalgia, purpura and } \\
\text { nephrotic range proteinuria }\end{array}$ & $\begin{array}{l}\text { PDN, } \\
\text { MTX, CYC, } \\
\text { rituximab }\end{array}$ & $\begin{array}{l}\text { Resolution of all symptoms attributed to } \mathrm{CV} \text { after } \\
\text { rituximab but progressive pulmonary hypertension } \\
\text { attributed to MCTD, treated with bosentan. }\end{array}$ \\
\hline 4 & $F / 49$ & $\begin{array}{l}\text { Type I cryoglobulinemia }(\operatorname{Ig} G \lambda) \\
2^{a x y} \text { to MGUS }\end{array}$ & $\begin{array}{l}\text { Arthralgia, myalgia, } \\
\text { purpura and leg ulcers }\end{array}$ & $P D N, C Y C$ & $\begin{array}{l}\text { Resolution of all symptoms, in complete remission under } \\
\text { low dose steroid. }\end{array}$ \\
\hline 5 & $F / 77$ & $\begin{array}{l}\text { Type III cryoglobulinemia } 2^{2 a y} \text { to } \\
\text { Sjögren's syndrome }\end{array}$ & $\begin{array}{l}\text { Arthralgia, myalgia, purpura and } \\
\text { neuropathy }\end{array}$ & $P D N, A Z A$ & $\begin{array}{l}\text { Amelioration of all symptoms. Residual purpura and } \\
\text { neuropathic complains responsive to prednisone. }\end{array}$ \\
\hline 6 & $F / 46$ & $\begin{array}{l}\text { Essential type III } \\
\text { cryoglobulinemia }\end{array}$ & $\begin{array}{c}\text { Arthralgia, myalgia and } \\
\text { neuropathy }\end{array}$ & $P D N, A Z A$ & $\begin{array}{l}\text { Amelioration of all symptoms. Residual neuropathic } \\
\text { complains responsive to prednisone. }\end{array}$ \\
\hline 7 & $M / 33$ & $\begin{array}{l}\text { Type III cryoglobulinemia } 2^{2 a y} \text { to } \\
\text { Sjögren's syndrome }\end{array}$ & $\begin{array}{l}\text { Arthralgia, myalgia, purpura and } \\
\text { neuropathy }\end{array}$ & $P D N, A Z A$ & $\begin{array}{l}\text { Resolution of all symptoms. Complete remission under low } \\
\text { dose prednisone and azathioprine. }\end{array}$ \\
\hline 8 & $F / 69$ & Essential Type III & $\begin{array}{c}\text { Arthralgia, myalgia, purpura / leg } \\
\text { ulcers and GN }\end{array}$ & $P D N, A Z A$ & $\begin{array}{l}\text { Resolution of all symptoms. Complete remission under low } \\
\text { dose prednisone and azathioprine. }\end{array}$ \\
\hline 9 & $\mathrm{~F} / 72$ &  & $\begin{array}{l}\text { Arthralgia, myalgia, purpura, } \\
\text { leg ulcers, neuropathy and GN }\end{array}$ & $P D N, A Z A$ & $\begin{array}{l}\text { Amelioration of all symptoms. Residual neuropathic } \\
\text { complains responsive to prednisone. }\end{array}$ \\
\hline
\end{tabular}

Abbreviations: $M=$ male; $F=$ female $C V=$ Cryoglobulinemic Vasculitis; $P D N=$ Prednisone; $C Y C=$ Cyclophosphamide; RPGN = Rapid Progressive Glomerulonephritis; $A Z A=$ azathioprine $M T X=$ methotrexate $M C T D=$ mixed connective tissue disease.

of HCV and non-HCV patients ${ }^{(4,6)}$. It is important to notice that those patients with type II mixed cryoglobulinemia presented evidence of complement consumption and rheumatoid factor activity.

This study presented lymphoproliferative characteristics in bone marrow biopsies in a significant proportion of the patients. This is consistent with the idea that cryoglobulinemia should not be understood as a simple autoimmune inflammatory disease. Ferri ${ }^{(8)}$ refers to cryoglobulinemia as "a crossroad between a classic autoimmune disorder and malignancy". Patients with cryoglobulinemia can develop a B cell lymphoma, usually after long time of treatment. This complication may be related to peripheral $B$ cell expansion and the lymphoid infiltrates observed in the liver and bone marrow of patients with cryoglobulinemia. These infiltrates have been regarded by some authors as "early lymphomas". However, unlike frank malignant lymphomas, they tend to remain unmodified for years or even decades, but they can be followed by overt lymphoid tumors 
in some patients. These characteristics justify the recent proposed term "monotypic lymphoproliferative disorder of undetermined significance (MLDUS)»(5,7) and it has clinical and therapeutic implications. Patients should be monitored for the development of overt lymphomas and those with refractory $C V$ may benefit with $B$ cell driven therapy.

Clinically, the cryoglobulinemic syndrome follows a relatively benign clinical course in most cases, whereas a moderate-severe clinical evolution may be observed in some patients whose prognosis is influenced by intensity of the inflammatory symptoms and target organ failure. Non$H C V, C V$ patients can be benefited with immunosuppressive treatment, which may include a combination of steroids, cytotoxic agents and plasma exchange ${ }^{(4-6)}$, as occurred in most of our patients. Nevertheless, three patients in our series proved refractory to this approach. Others have also reported refractory $C V^{(5,6,9)}$ and therefore there is an obvious need for new treatments.

Rituximab is a human/mouse chimeric monoclonal antibody that reacts specifically with CD20 antigen - a transmembrane protein present during the maturation of $B$ lymphocytes. This molecule induces complement and antibody dependent cytotoxicity ${ }^{(10)}$. By depleting $B$ cells, rituximab has the potential to reduce the clonal $B$ cell expansion and the development of plasma cells, thereby limiting cryoglobulin production. Some authors have shown promising results with rituximab in refractory $C V$, but the most patients were HCV positive and the amount of experience is still limited ${ }^{(9-13)}$. In our study, the patients who were refractory to conventional immunosuppressive agents responded well to rituximab. Regarding safety, there were no serious adverse events. Patient 3 developed a progressive pulmonary hypertension after the treatment with rituximab. This is a known complication of MCTD and therefore it was attributed to the underlying rheumatic disease. So far, there are no other reports of pulmonary hypertension in patients receiving rituximab, but other vascular problems such as retinal vein thrombosis have been described ${ }^{(1)}$.

In conclusion, non-HCV cryoglobulinemia may present itself as a systemic vasculitis, mainly manifesting cutaneous symptoms, neuropathy and/or GN as clinical features. It should not be understood as a simple inflammatory disease, since most patients have presented evidence of a lymphoproliferative disorder. Treatment should include steroids and immunosuppressive agents. Refractory patients may benefit of B-cell depletion with rituximab. Prospective controlled trials are wanted to confirm this beneficial therapeutic effect, to determine the optimal dosage and the efficacy of combined therapy with other immunosuppressive treatments.

Declaramos a inexistência de conflitos pertinentes de interesse.

\section{REFERÊNCIAS}

1. Brouet JC, Clauvel JP, Danon F, Klein M, Seligmann M: Biologic and clinical significance of cryoglobulins: A report of 86 cases. Am J Med 57: 577-85, 1974.

2. Meltzer M, Franklin EC, Elias K et al: Cryoglobulinemia. A clinical and laboratory study II. Cryoglobulins with rheumatoid factor activity. Am J Med 40:837-56, 1966.

3. Agnello V, Chung RT, Kaplan LM: A role for hepatitis C virus infection in type II cryoglobulinemia. N Engl J Med 327:1490-5, 1992.

4. Trejo O, Ramos-Casals M, García-Carrasco M et al: Cryoglobulinemia: Study of etiologic factors and clinical and immunologic features in 443 patients from a single center. Medicine (Baltimore) 80: 252-62, 2001

5. Ferri C, Sebastiani M, Giuggioli D et al: Mixed Cryoglobulinemia: demographic, clinical, and serologic features and survival in 231 patients. Semin Arthritis Rheum 33: 355-374, 2004.

6. Rieu V, Cohen P, André MH et al: Characteristics and outcome in 49 patients with symptomatic cryoglobulinemia. Rheumatology 41: 290-300, 2002

7. Ferri C, Zignego AL, Pileri SA: Cryoglobulins. J Clin Pathol 55:

4-13, 2002.

8. Ferri C, La Civita L, Longombardo G et al: Mixed cryoglobulinemia: a cross-road between autoimmune and lymphoproliferative disorders. Lupus 7: 275-9, 1998.

9. Sansonno D, De Re V, Lauletta G, Tucci FA, Boiocchi M, Dammacco F: Monoclonal antibody treatment of mixed cryoglobulinemia resistant to interferon alpha with an antiCD20. Blood 101: 3818-26, 2003.

10. Silverman GJ, Weisman S: Rituximab therapy and autoimmune disorders: prospects for anti-B cell therapy. Arthritis Rheum 48: 1484-92, 2003.

11. Zaja F, De Vita S, Mazzaro C et al: Efficacy and safety of rituximab in type II mixed cryoglobulinemia. Blood 101: 3827-34, 2003

12. Arzoo K, Sadeghi S, Liebman HA: Treatment of refractory antibody mediated autoimmune disorders with an anti-CD20 monoclonal antibody (rituximab). Ann Rheum Dis 61: 922-4, 2002.

13. Ghijsels E, Lerut E, Vanrenterghem Y, Kuypers D: Anti-CD20 monoclonal antibody (rituximab) treatment for hepatitis $\mathrm{C}$ negative therapy-resistant essential mixed cryoglobulinemia with renal and cardiac failure. Am J Kidney Dis 43: e34-e38, 2004. 